\title{
ОЦЕНКА ЭФФЕКТИВНОСТИ ИСКУССТВЕННОГО КОРМА ИЗ НАСЕКОМЫХ ПРИ ВЫРАЩИВАНИИ КОКЦИНЕЛЛИД, ИСПОЛЬЗУЕМЫХ ДЛЯ БИОЛОГИЧЕСКОЙ ЗАЩИТЫ РАСТЕНИЙ В РАЗЛИЧНЫХ АГРОЭКОСИСТЕМАХ
}

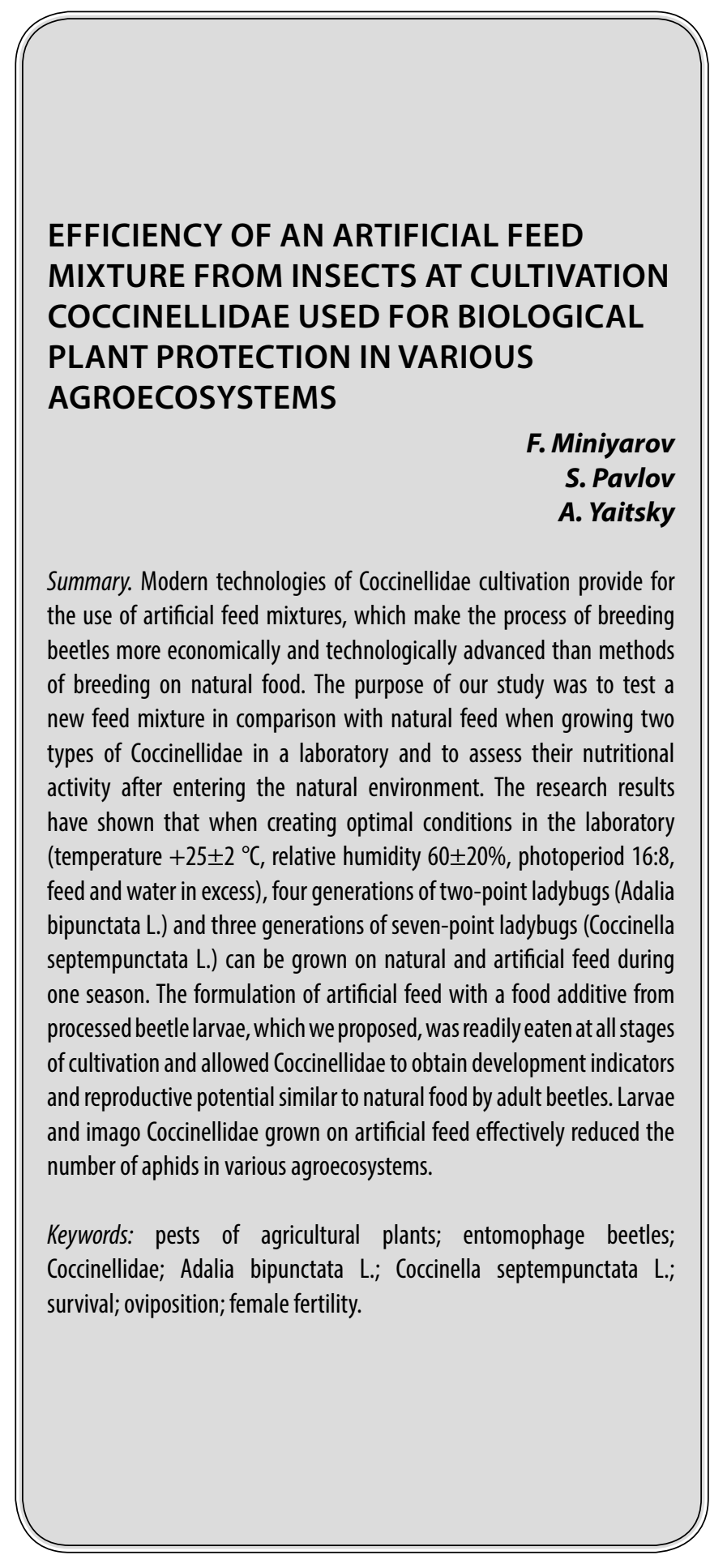

\author{
Минияров Фарит Талгатович \\ К.б.н., дочент, ФГБОУ ВО «Астраханский \\ государственный университет» \\ fminiyarov@mail.ru \\ Павлов Сергей Иванович \\ К.б.н., дочент, ФГБОУ ВО «Самарский \\ государственный сочиально-педагогический \\ университет» \\ pavlov@sgspu.ru \\ Яичкий Андрей Степанович \\ Старший преподаватель, ФГБОУ ВО «Самарский \\ государственный сочиально-педагогический \\ университет» \\ yaitsky@sgspu.ru
}

Аннотация. Современные подходы к выращиванию кокцинеллид предусматривают использование искусственных кормовых смесей, позволяющих сделать процесс разведения жуков более экономичным и технологичным, чем методы разведения на естественной пище. Целью исследования была проверка нового состава кормосмеси, по сравнению с естественным кормом, при выращивании в условиях лаборатории двух видов кокцинеллид (Adalia bipunctata L., Coccinella septempunctata L.) и оценка их пищевой активности после вселения в естественную среду. Результаты исследований показали, что при создании в лаборатории оптимальных условий содержания (температура $+25 \pm 2{ }^{\circ} \mathrm{C}$, относительная влажность $60 \pm 20 \%$, фотопериод 16:8, корм и вода в избытке) можно вырастить на естественном и искусственном корме 4 поколения двухточечной коровки (Adalia bipunctata L.) и 3 поколения семиточечной коровки (Coccinella septempunctata L.) в течение одного сезона. Искусственный корм, изготовленный по предложенной нами рецептуре с пищевой добавкой из переработанных личинок жуков-бронзовок, охотно поедался на всех стадиях выращивания и позволил кокцинеллидам получить схожие с естественной пищей показатели развития и репродуктивный потенциал у взрослых особей жуков. Выращенные на искусственном корме личинки и имаго кокцинеллид эффективно снижали численность тли в различных агроэкосистемах.

Ключевые слова: вредители сельскохозяйственных растений; жуки-энтомофаги; кокцинеллиды; двухточечная коровка; семиточечная коровка; выживаемость; яйцекладка; плодовитость самок. 


\section{Введение}

B ыпуск естественных хищников активно используется в биологической защите сельскохозяйственных растений от вредителей в органическом земледелии [1, с. 12-15; 2, р. 295-321; 3, р. 255-267]. В качестве эффективного хищника могут использоваться личинки и взрослые особи божьих коровок (Coleoptera, Coccinellidae) [4, р. 338-341]. Отлавливание жуков-кокцинеллид в естественной среде используется редко [5, р. 306-312], чаще жуки выращиваются в искусственных условиях с дальнейшим вселением в защищаемые агроэкосистемы [6, р. 115-117].

В современных технологиях выращивания кокцинеллид наблюдается переход от затратного подхода с использованием естественного корма к более экономичному и технологичному методу разведения с использованием искусственных кормосмесей [7, р. 165173; 8, р. 47-51; 9, р. 111-120]. Поэтому исследования по сбалансированности и подбору новых ингредиентов искусственных кормов, а также их влиянию на биологические характеристики выращиваемых жуков, являются актуальными [10, р. 575-583; 11, р. 601-619; 12, р. 242-252].

\section{Цель исслеАования}

Проверка нового состава кормосмеси, по сравнению с естественным кормом, при выращивании в условиях лаборатории двух видов кокцинеллид (Adalia bipunctata L., Coccinella septempunctata L.) и оценка их пищевой активности после вселения в естественную среду.

\section{Материалы и методика исслеАований}

Изучение насекомых на различных стадиях развития проводилось как в искусственных условиях - на базе лаборатории экспериментальной зоологии Астраханского государственного университета, так и в естественной среде - на базе региональных фермерских хозяйств по общепринятым методикам [13; 14; 15]. Основными объектами исследования являлись два вида жуков: двухточечная коровка Adalia bipunctata и семиточечная коровка Coccinella septempunctata (Coleoptera, Coccinellidae) на различных стадиях жизненного цикла. Данные виды кокцинеллид являются наиболее распространёнными в исследуемом регионе и активными хищниками многих вредителей сельскохозяйственных растений. Кроме этого, выбор данных видов обусловлен возможностью их использования для расселения на растениях, выращиваемых как в теплицах, так и в открытом грунте, не опасаясь инвазии [16, с. 98-110; 17, с. 32-38].
Пойманные в естественной среде самки и самцы кокцинеллид были помещены в разные по видам инсектарии (объемом 20 л). В каждом инсектарии были размещены сложенные в несколько слоев бумажные полотенца для откладки на них яиц. Полученные яйцекладки перемещались в отдельные контейнеры (объемом 0,5 л) до выхода личинок. Случайным образом отобранные личинки жуков 1-го возраста для каждого вида $(n=100)$ размещались по 10 особей в садки (объемом 2,5 л) для эксперимента и контроля. Условия содержания в инсектариях, контейнерах и садках поддерживались на уровне: температура $+25 \pm 2{ }^{\circ} \mathrm{C}$, относительная влажность $60 \pm 20 \%$, фотопериод 16:8 (день: ночь). Два раза в день осуществляли кормление (в избытке), замеры и подсчёт жуков, а также проводили уборку в каждом садке. Для обеспечения жуков водой в садках имелась специальная поилка [18, p. 42-48].

В контрольных садках кормление личинок и имаго кокцинеллид осуществлялось разновозрастными личинками и взрослыми особями розанной тли Macrosiphum rosae L. (Aphididae, Hemiptera), а в экспериментальных садках - искусственной кормовой смесью. Основой кормовой смеси был уже опробованный на семиточечной коровке состав [19, с. 26-31], кроме декапсулированных яиц Artemia salina L. (Anostraca, Artemiidae). Вместо них мы использовали переработанных личинок жуков-бронзовок из подсемейства Cetoniinae (Coleoptera, Scarabaeidae). После изменения состав кормовой смеси выглядел следующим образом (на 100 г): дистиллированная вода (50 г), пищевая добавка из насекомых (15 г), свиная печень (10 г), сахароза (10 г), куриный желток (5 г), растительное масло (2 г), агар-агар (3 г) и др. (5 г).

Оценивали следующие показатели выращивания кокцинеллид: выживаемость преимагинальных стадий в\% (по доле имаго от числа личинок 1-го возраста), продолжительность развития преимагинальных стадий в сутках (от выхода из яйца до имаго), вес имаго начальный при вылете с точностью до 0,1 мг, продолжительность преовипозиционного периода в сутках (от линьки на имаго до первой яйцекладки), объём первой яйцекладки (по среднему числу яиц), итоговая плодовитость самок (по среднему числу яиц, отложенных отдельными самками за всё время содержания). Результаты усредняли по группам (контроль и эксперимент) и поколениям каждого вида кокцинеллид. Рассчитывали среднеквадратичное отклонение средних и процентов. Предварительно результаты исследований были проверены на нормальность распределения и однородность дисперсий с помощью критерия Шапиро-Уилка (W-тест) и теста Левене. В дальнейшем анализ достоверности различий был проведен с использованием различных критериев: для сравнения групп (контроль и экспери- 


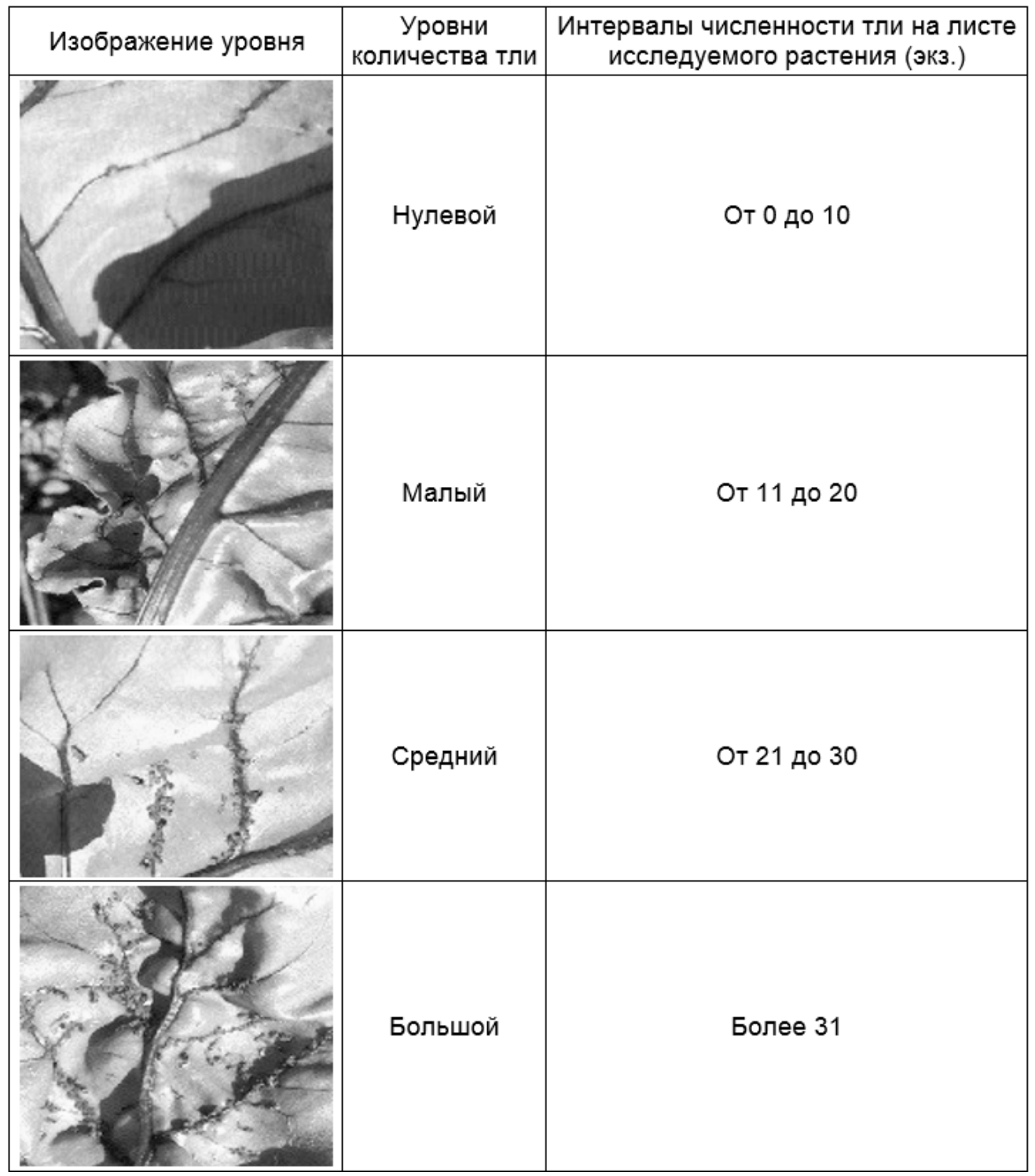

Рис. 1. Уровни численности тли на листьях свёклы обыкновенной (Beta vulgaris)

мент) — критерий Манна-Уитни (U); поколений — критерий Краскела-Уоллиса (Н) [20, с. 12-15].

На следующем этапе исследования в течение 5 недель мы оценивали эффективность выращенных на искусственном корме кокцинеллид в защите от тли сельскохозяйственных растений в естественных условиях.

Для исследования были отобраны:

1. два разнесенных (более 500 м друг от друга) участка в плодовых садах, в которых выращивались яблони (Malus domestica L.) сорта Семиренко, доминирующий вид тли: зеленая яблонная (Aphis pomi De Geer);

2. два поля с выращиваемой свёклой обыкновенной (Beta vulgaris L.) сорта Ленинградская округлая, доминирующий вид тли: свекловичная или бобовая (Aphis fabae Scopoli);

3. две открытые теплицы с выращиваемыми огурцами (Cucumis sativus L.) гибрида F1 Атлет, доминирующий вид тли: бахчевая (Aphis gossypii Glover).

Вселение жуков на экспериментальные участки осуществлялось на стадиях личинки 3-4 возрастной стадии и имаго 1 раз в неделю. Отбор проб в эксперименте и контроле проводился 2 раза в неделю по десяти случайно выбранным участкам площадью 1 м².

Для унификации и ускорения отбора проб были разработаны шкалы с различными уровнями количества тли на листьях исследуемых растений. Для примера при- 
Таблица 1. Средние значения показателей развития и репродуктивного потенциала кокцинеллид при кормлении искусственным (эксперимент) и естественным (контроль) кормом в лабораторных условиях

\begin{tabular}{|c|c|c|c|c|c|c|c|c|}
\hline \multirow[t]{2}{*}{ № } & \multirow[t]{2}{*}{ Показатели } & \multirow[t]{2}{*}{ Группа/ критерий } & \multicolumn{3}{|c|}{$\begin{array}{l}\text { Двухточечная коровка (Adalia } \\
\text { bipunctata) }\end{array}$} & \multicolumn{3}{|c|}{$\begin{array}{l}\text { Семиточечная коровка } \\
\text { (Coccinella septempunctata) }\end{array}$} \\
\hline & & & KO & Cp4 & КУ & KO & Cp3 & Kу \\
\hline \multirow{3}{*}{1} & \multirow{3}{*}{$\begin{array}{l}\text { Выживаемость } \\
\text { преимагинальных стадий,\% }\end{array}$} & Эксперимент & $400^{*}$ & $59,00 \pm 7,09$ & $\begin{array}{l}H=3,391 \\
p=0,335\end{array}$ & $300^{*}$ & $59,00 \pm 8,03$ & $\begin{array}{l}H=0,675 \\
p=0,714\end{array}$ \\
\hline & & Контроль & $400^{*}$ & $70,75 \pm 10,95$ & $\begin{array}{l}H=0,726 \\
p=0,867\end{array}$ & $300^{*}$ & $75,00 \pm 10,42$ & $\begin{array}{l}H=0,136 \\
p=0,934\end{array}$ \\
\hline & & $\begin{array}{l}\text { Критерий } \\
\text { по группам }\end{array}$ & - & $\begin{array}{l}U ; \\
p=0,000\end{array}$ & - & - & $\begin{array}{l}\text { U; } \\
p=0,000\end{array}$ & - \\
\hline \multirow{3}{*}{2} & \multirow{3}{*}{$\begin{array}{l}\text { Продолжительность развития } \\
\text { преимагинальных стадий, суток }\end{array}$} & Эксперимент & 236 & $21,67 \pm 4,45$ & $\begin{array}{l}H=2,847 \\
p=0,416\end{array}$ & 177 & $25,55 \pm 4,17$ & $\begin{array}{l}H=0,464 \\
p=0,793\end{array}$ \\
\hline & & Контроль & 283 & $21,05 \pm 3,65$ & $\begin{array}{l}H=9,053 \\
p=0,029\end{array}$ & 225 & $24,13 \pm 4,06$ & $\begin{array}{l}H=5,557 \\
p=0,062\end{array}$ \\
\hline & & $\begin{array}{l}\text { Критерий } \\
\text { по группам }\end{array}$ & - & $\begin{array}{l}\text { U; } \\
p=0,255\end{array}$ & - & - & $\begin{array}{l}\text { U; } \\
p=0,000\end{array}$ & - \\
\hline \multirow{3}{*}{3} & \multirow{3}{*}{$\begin{array}{l}\text { Вес имаго начальный (при } \\
\text { вылете), мг }\end{array}$} & Эксперимент & 236 & $30,6 \pm 9,04$ & $\begin{array}{l}H=5,463 \\
p=0,141\end{array}$ & 177 & $50,5 \pm 13,37$ & $\begin{array}{l}H=1,316 \\
p=0,518\end{array}$ \\
\hline & & Контроль & 283 & $32,6 \pm 9,69$ & $\begin{array}{l}H=0,930 \\
p=0,818\end{array}$ & 225 & $53,1 \pm 13,79$ & $\begin{array}{l}H=4,889 \\
p=0,087\end{array}$ \\
\hline & & $\begin{array}{l}\text { Критерий } \\
\text { по группам } \\
\end{array}$ & - & $\begin{array}{l}U ; \\
p=0,026\end{array}$ & - & - & $\begin{array}{l}U ; \\
p=0,036\end{array}$ & - \\
\hline \multirow{3}{*}{4} & \multirow{3}{*}{$\begin{array}{l}\text { Продолжительность } \\
\text { преовипозиционного периода } \\
\text { (до первой яйцекладки), суток }\end{array}$} & Эксперимент & 116 & $4,91 \pm 1,67$ & $\begin{array}{l}H=1,254 \\
p=0,740\end{array}$ & 84 & $7,52 \pm 1,93$ & $\begin{array}{l}H=1,236 \\
p=0,539\end{array}$ \\
\hline & & Контроль & 140 & $5,10 \pm 1,59$ & $\begin{array}{l}H=2,729 \\
p=0,435\end{array}$ & 112 & $7,03 \pm 1,79$ & $\begin{array}{l}H=1,179 \\
p=0,555\end{array}$ \\
\hline & & $\begin{array}{l}\text { Критерий } \\
\text { по группам }\end{array}$ & - & $\begin{array}{l}\mathrm{U} ; \\
\mathrm{p}=0,419\end{array}$ & - & - & $\begin{array}{l}\mathrm{U} ; \\
\mathrm{p}=0,109\end{array}$ & - \\
\hline \multirow{3}{*}{5} & \multirow{3}{*}{ Объем первой яйцекладки, яиц } & Эксперимент & 116 & $40,17 \pm 14,87$ & $\begin{array}{l}H=7,434 \\
p=0,059\end{array}$ & 84 & $31,58 \pm 12,73$ & $\begin{array}{l}H=0,006 \\
p=0,997\end{array}$ \\
\hline & & Контроль & 140 & $45,10 \pm 11,93$ & $\begin{array}{l}H=2,815 \\
p=0,421\end{array}$ & 112 & $37,21 \pm 16,31$ & $\begin{array}{l}H=1,754 \\
p=0,416\end{array}$ \\
\hline & & $\begin{array}{l}\text { Критерий } \\
\text { по группам }\end{array}$ & - & $\begin{array}{l}U ; \\
p=0,033\end{array}$ & - & - & $\begin{array}{l}U ; \\
p=0,019\end{array}$ & - \\
\hline \multirow{3}{*}{6} & \multirow{3}{*}{$\begin{array}{l}\text { Итоговая плодовитость самок, } \\
\text { яиц }\end{array}$} & Эксперимент & 116 & $\begin{array}{l}931,60 \pm \\
115,47 \\
\end{array}$ & $\begin{array}{l}H=0,065 \\
p=0,996\end{array}$ & 84 & $\begin{array}{l}651,14 \pm \\
121,66 \\
\end{array}$ & $\begin{array}{l}H=1,154 \\
p=0,562\end{array}$ \\
\hline & & Контроль & 140 & $\begin{array}{l}951,79 \pm \\
154,74 \\
\end{array}$ & $\begin{array}{l}H=0,382 \\
p=0,944\end{array}$ & 112 & $\begin{array}{l}656,65 \pm \\
111,84 \\
\end{array}$ & $\begin{array}{l}H=0,172 \\
p=0,918\end{array}$ \\
\hline & & $\begin{array}{l}\text { Критерий } \\
\text { по группам }\end{array}$ & - & $\begin{array}{l}\mathrm{U} ; \\
\mathrm{p}=0,320\end{array}$ & - & - & $\begin{array}{l}\mathrm{U} ; \\
\mathrm{p}=0,435\end{array}$ & - \\
\hline
\end{tabular}

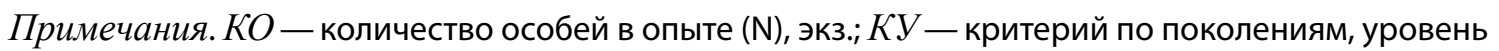

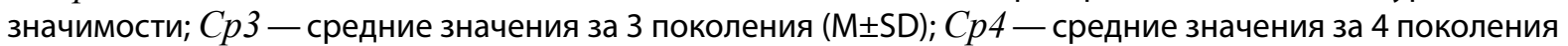
$(\mathrm{M} \pm \mathrm{SD}) ; M \pm S D$ - среднее значение \pm среднеквадратичное отклонение; $H$ - критерий КраскелаУоллиса; $U$ - критерий Манна-Уитни; $p$ - уровень значимости критерия (полужирным выделено статистически значимое отличие при $р<0,05)$; * исходное количество личинок.

ведена шкала для визуальной и количественной оценки уровня численности тли на листьях свёклы обыкновенной (рис. 1). Были определены 4 уровня численности тли на одном листе исследуемого растения: нулевой (от 0 до 10 экз.), малый (от 11 до 20 экз.), средний (от 21 до 30 экз.) и большой (более 31 экз.).
Сравнение уровней численности тли по разработанным шкалам проводили по группам (контроль и эксперимент) отдельно для плодовых садов, сельскохозяйственных полей и открытых теплиц. Анализ достоверности различий был проведен с использованием критерия Манна-Уитни (U) для исходных данных [20, с. 12-15]. 
Статистический анализ результатов всех экспериментов был проведён с использованием программы Statistica 13.5 (2018) (TIBCO Software Inc.).

\section{Результаты исслеАований и их обсужАение}

Результаты выращивания кокцинеллид при кормлении искусственным и естественным кормом в лабораторных условиях

Для исследования по 10 личинок 1-го возраста каждого вида кокцинеллид были размещены в 10 контрольных садков с кормлением естественной пищей и в 10 экспериментальных садков с кормлением искусственным кормом (табл. 1). Всего в опытах было задействовано 40 садков.

За вегетационный период (с марта по октябрь) в условиях лаборатории были получены 4 поколения двухточечной коровки (Adalia bipunctata) и 3 поколения семиточечной коровки (Coccinella septempunctata), что отличается от двух поколений божьих коровок в природных популяциях [16, с. 98-110; 17, с. 32-38]. Увеличение количества поколений у различных видов кокцинеллид отмечается при соблюдении оптимальных условий содержания (температура $+25 \pm 2{ }^{\circ} \mathrm{C}$, относительная влажность $60 \pm 20 \%)$ и избыточном рационе кормления. Схожие результаты по четырем поколениям были получены по двухточечной коровке только при кормлении естественной пищей [21, с. 88-90].

Средняя выживаемость преимагинальных стадий кокцинеллид за все поколения составляла в контроле около $70 \%$ у двухточечной коровки и $75 \%$ у семиточечной, в эксперименте - 59\% у обоих видов (табл. 1). Полученные результаты выживаемости при кормлении искусственным кормом являлись статистически значимо ниже (при уровне значимости критерия $U \mathrm{p}<0,001$ ).

Кроме этого, использование искусственного корма статистически значимо повлияло (при уровне $\mathrm{p}<0,05$ ) на вес имаго начальный при вылете и объём первой яйцекладки обоих видов жуков (уровни значимости: $p=0,026$ и $p=0,033 ; p=0,036$ и $p=0,019$ по видам, соответственно). Так, средний вес имаго у двухточечной коровки при вылете составлял 30,6士9,04 мг при кормлении искусственным кормом и 32,6士9,69 мг в контроле, а у имаго семиточечной коровки - 50,5 +13,37 мг в экспериментальной группе и 53,1土13,79 мг при кормлении естественной пищей. Также среднее число яиц в первой яйцекладке

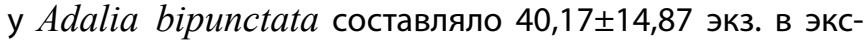

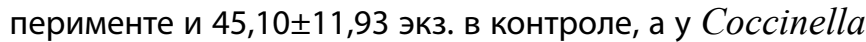

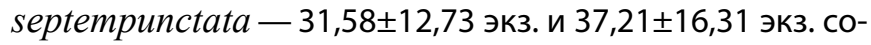
ответственно (табл. 1).
Схожее снижение выживаемости, веса имаго и объемов первой кладки у кокцинеллид отмечено и другими исследователями, и объясняется недостаточной сбалансированностью используемого искусственного корма по сравнению с естественным кормом [10, р. 575-583; 11, p. 601-619; 12, p. 242-252].

Остальные показатели выращивания кокцинеллид при кормлении искусственным и естественным кормом в лабораторных условиях статистически не отличались и были схожи по группам (табл. 1).

При изучении развития и репродуктивного потенциала кокцинеллид в разных поколениях мы наблюдали сходные значения как у двухточечной коровки, так и у семиточечной коровки. Единственное статистически значимое отличие (при уровне $p<0,05)$ было зафиксировано в продолжительности развития преимагинальных стадий Adalia bipunctata в контрольной группе (табл. 1).

Эффективность выращенных на искусственном корме кокцинеллид в защите сельскохозяйственных растений от тли

После еженедельного вселения личинок и имаго двухточечной и семиточечной коровок на яблони в плодовых садах было отмечено статистически достоверное снижение численности (при уровне $р<0,05$ ) по всем уровням, кроме нулевого. Так, количество зеленой яблонной тли (Aphis pomi) на листьях яблони, на экспериментальных участках с нулевым уровнем уменьшилось с 21,28\% в эксперименте до 9,38\% в контроле, а с малым уровнем - с 28,60\% до $11,68 \%$ соответственно. В то же время на листьях яблони увеличивалось количество тли со средним и большим уровнями: с 31,06\% и 19,06\% в эксперименте до 42,98\% и 35,96\% в контроле (рис. 2).

При вселении кокцинеллид на свёклу, выращиваемую на сельскохозяйственных полях, мы наблюдали статистически достоверное снижение численности тли (при уровне $\mathrm{p}<0,05)$ по всем уровням. Так, количество свекловичной тли (Aphis fabae) на листьях свёклы на экспериментальных участках с нулевым уровнем уменьшилось с 27,94\% в эксперименте до 17,40\% в контроле, а с малым уровнем - с 31,62\% до $18,12 \%$ соответственно. В то же время на листьях свёклы увеличивалось количество тли со средним и большим уровнями соответственно: с 19,46\% и 20,98\% в эксперименте до 32,34\% и $32,14 \%$ в контроле (рис. 2).

При вселении кокцинеллид на огурцы, выращиваемые в открытых теплицах, было отмечено статистически достоверное снижение численности тли (при уровне 


\section{Плодовые сады}

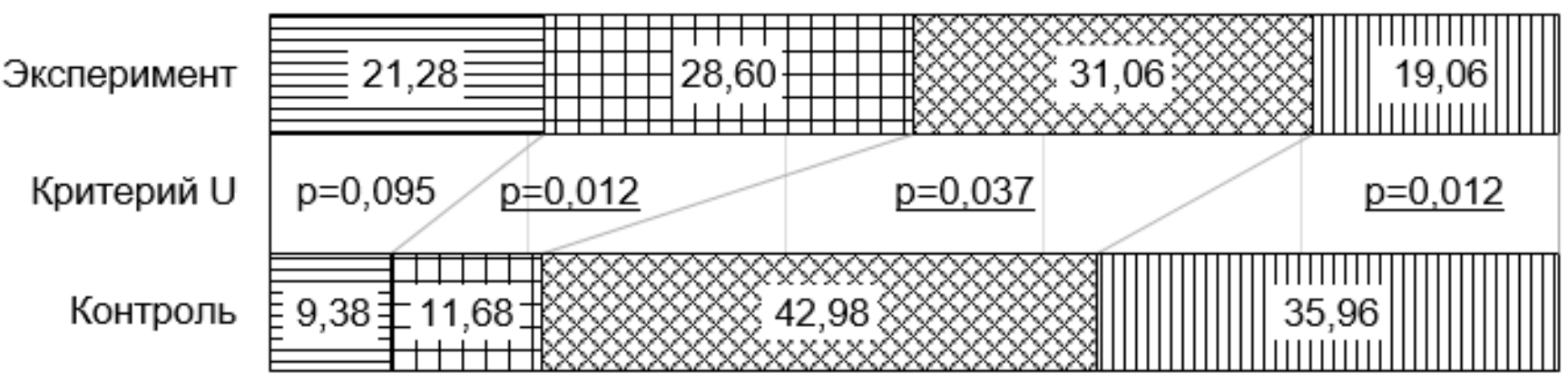

\section{Сельскохозяйственные поля}

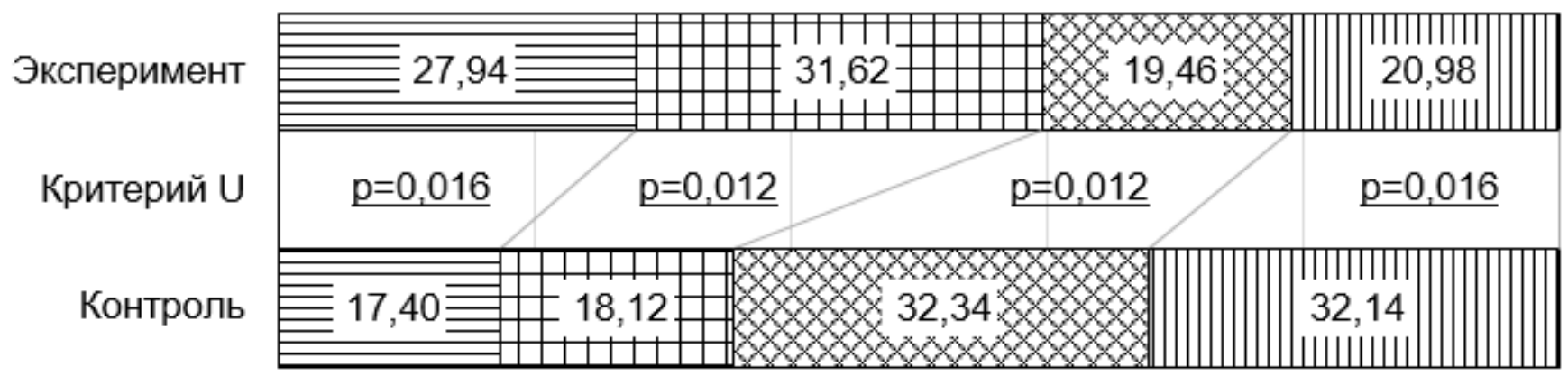

\section{Открытые теплицы}

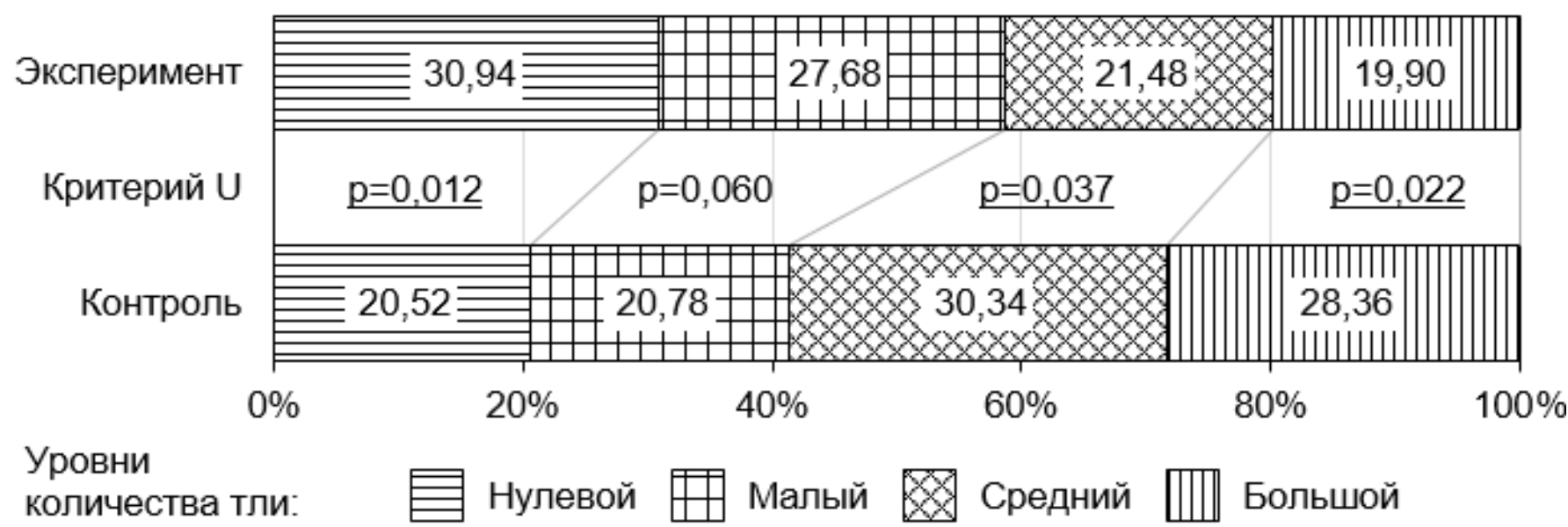

Рис. 2. Сравнительная эффективность (\%) кокцинеллид по уровням количества тли после вселения в различные агроэкосистемы. Примечания: критерий U — критерий Манна-Уитни; р - уровень значимости критерия (подчёркнуты статистически значимые отличия при $p<0,05$ )

$\mathrm{p}<0,05)$ по всем уровням, кроме малого. Так, количество бахчевой тли (Aphis gossypii) на листьях огурцов на экспериментальных участках с нулевым уровнем уменьшилось с 30,94\% в эксперименте до 20,52\% в контроле, а с малым уровнем - с 27,68\% до $20,78 \%$ соответственно. В то же время на листьях огурцов увеличивалось количество тли со средним и большим уровнями соот- ветственно: с 21,48\% и 19,90\% в эксперименте против $30,34 \%$ и 28,36\% в контроле (рис. 2).

Эти результаты согласуются с данными о снижении численности тли другими видами коровок семейства Coccinellidae в различных агроэкосистемах [22, с. 8-12; 23, p. 92-102; 24, p. 410-415; 25, p. 83-91; 26, p. 1-17]. 


\section{Зак^ючение}

Таким образом, при создании в лаборатории оптимальных условий содержания (температура $+25 \pm 2{ }^{\circ} \mathrm{C}$, от-

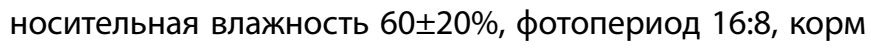
и вода в избытке) можно вырастить на естественном и искусственном корме 4 поколения двухточечной коровки (Adalia bipunctata) и 3 поколения семиточечной коровки (Coccinella septempunctata) в течение одного сезона.

При этом были получены сравнимые показатели выращивания кокцинеллид как на естественном корме, так и на искусственном. Так, на искусственном корме выживаемость преимагинальных стадий жуков составляла 59\% от числа личинок 1-го возраста при продолжитель- ности развития 21-25 суток до имаго, средний вес которых составлял 30-50 мг, продолжительность периода до первой яйцекладки - 5-7 суток при объеме первой яйцекладки - 30-40 яиц и итоговой плодовитости самок - 650-930 яиц за сезон.

В ходе полевых исследований установлено, что на экспериментальных участках в различных агроэкосистемах после вселения кокцинеллид наблюдалось снижение численности тли рода Aphis: A. pomi с 79\% до 50\% на листьях яблони со средним и большим уровнями зелёной яблонной тли; $A$. fabae с $65 \%$ до $40 \%$ на листьях свёклы со средним и большим уровнями свекловичной тли; A. gossypii с 59\% до 41\% на листьях огурцов со средним и большим уровнями бахчевой тли.

\section{ЛИТЕРАТУРА}

1. Монастырский А.Л., Горбатовский В.В. Массовое разведение насекомых для биологической защиты растений: справочник. М.: Агропромиздат, 1991. 240 с.

2. Obrycki J., Kring T. Predaceous Coccinellidae in biological control // Annual Review of Entomology. 1998. Vol. 43. P. 295-321. D0l: 10.1146/annurev.ento.43.1.295.

3. Evans E.W. Lady beetles as predators of insects other than Hemiptera // Biological Control. 2009. Vol. 51, iss. 2. P. 255-267. D0l: 10.1016/j.biocontrol.2009.05.011.

4. Hajek A.E., Eilenberg J. Natural enemies: an introduction to biological control. 2nd ed. Cambridge: Cambridge University Press, 2018.440 p. D0l: $10.1017 / 9781107280267$.

5. Riddick E.W., Cottrell T.E., Kidd K.A. Natural enemies of the Coccinellidae: parasites, pathogens, and parasitoids // Biological Control. 2009. Vol. 51, iss. 2. P. 306-312. DOl: 10.1016/j.biocontrol.2009.05.008.

6. Altieri M.A., Nicholls C.I. Vegetational designs to enhance biological control of insect pests in agroecosystems // Natural enemies of insect pests in neotropical agroecosystems / B. Souza, L. Vázquez, R. Marucci (eds.). Springer, 2019. P. 3-13. D0I: 10.1007/978-3-030-24733-1_1.

7. Ashraf M., Ishtiaq M., Asif M., Adrees M., Ayub M., Tariq M., Awan M.N. A study on laboratory rearing of lady bird beetle (Coccinella septempunctata) to observe its fecundity and longevity on natural and artificial diets // International Journal of Biology. 2010. Vol. 2, № 1. P. 165-173. D0I: 10.5539/ijb.v2n1p165.

8. Sarwar M., Saqib S.M. Rearing of predatory seven spotted ladybird beetle Coccinella septempunctata L. (Coleoptera: Coccinellidae) on natural and artificial diets under laboratory conditions // Pakistan Journal of Zoology. 2010. Vol. 42 (1). P. 47-51.

9. Tan X.-L., Zhao J., Wang S., Zhang F. Optimization and evaluation of microencapsulated artificial diet for mass rearing the predatory ladybird Propylea japonica (Coleoptera: Coccinellidae) // Insect Science. 2014. Vol. 22, iss. 1. P. 111-120. D0l: 10.1111/1744-7917.12098.

10. Riddick E.W., Wu Z., Guadalupe Rojas M. Potential utilization of Artemia franciscana eggs as food for Coleomegilla maculate // BioControl. 2014. Vol. 59. P. 575-583. DOI: $10.1007 /$ s10526-014-9597-4.

11. Sun Y.-X., Hao Y.-N., Riddick E.W., Liu T.-X. Factitious prey and artificial diets for predatory lady beetles: current situation, obstacles, and approaches for improvement: a review // Biocontrol Science and Technology. 2017. Vol. 27, iss. 5. P. 601-619. D0I: 10.1080/09583157.2017.1324112.

12. Cheng Y., Zhi J., Li F., Jin J., Zhou Y. An artificial diet for continuous maintenance of Coccinella septempunctata adults (Coleoptera: Coccinellidae) // Biocontrol Science and Technology. 2018. Vol. 28, iss. 3. P. 242-252. D0l: 10.1080/09583157.2018.1439450.

13. Фасулати К.К. Полевое изучение наземных беспозвоночных: учеб. пособие для студ. биол. спец. ун-тов. 2-е изд., доп. и перераб. / под ред. К.К. Фасулати. М.: Высшая школа, 1971.424 с.

14. Цуриков М.Н., Цуриков С.Н. Природосберегающие методы исследования беспозвоночных животных в заповедниках России: труды Ассоциации особо охраняемых природных территорий Центрального Черноземья России. Вып. 4. Тула, 2001. 130 с.

15. Prezoto F., Maciel T.T., Barbosa B.C., Sarmiento C.E. Social wasp sampling methods // Measuring arthropod biodiversity / J.C. Santos, G.W. Fernandes (eds.). Springer, 2021. P. 85-99. D0l: 10.1007/978-3-030-53226-0_4.

16. Хабибуллин В.Ф., Степанова Р.К., Хабибуллин А.Ф. Жуки-коровки (Coleoptera, Coccinellidae) Республики Башкортостан: учеб. пособие для студ. биол. спец. вузов. Уфа: РИО БашГУ, 2004. 110 c.

17. Минияров Ф.Т., Павлов С.И., Яицкий А.С. Питание семиточечной коровки Coccinella septempunctata L. (Coleoptera, Coccinellidae) на различных стадиях жизненного цикла // Самарский научный вестник. 2019. Т. 8, № 2 (27). С. 32-38. D0I: 10.17816/snv201982106.

18. Hesler L.S., McNickle G., Catangui M.A., Losey J.E., BeckendorfE.A., Stellwag L., Brandt D.M., Bartlett P.B. Method for continuously rearing Coccinella lady beetles (Coleoptera: Coccinellidae) // The Open Entomology Journal. 2012. Vol. 6. P. 42-48. D0I: 10.2174/1874407901206010042.

19. Минияров Ф.Т., Павлов С.И., Яицкий А.С. Длительность развития, выживаемость и плодовитость Coccinella septempunctata L. (Coleoptera, Coccinellidae) при искусственном выращивании на различных кормовых смесях // Современная наука: актуальные проблемы теории и практики. Серия «Естественные и технические науки». 2019. № 11. С. 26-31. 
20. Матвеева Н.М., Валеева А.А. Статистическая обработка результатов полевых агрохимических исследований с помощью пакета StatGraphics Plus for Windows: учеб.-метод. пособие для студ. биолого-почвенного факультета. Казань: Казанский университет, 2012. 63 с.

21. Тюмасева 3.И. Кокцинеллиды Урала и сопредельных территорий. Челябинск: Изд-во Челяб. гос. пед. ун-та, 2013. 248 с.

22. Семьянов В.П. Разведение, длительное хранение и применение тропических видов кокцинеллид для борьбы с тлями в теплицах. М.: Товарищество научных изданий КМК, 2006. 29 с.

23. Yang N.-W., Zang L.-S., Wang S., Guo J.-Y., Xu H.-X., Zhang F., Wan F.-H. Biological pest management by predators and parasitoids in the greenhouse vegetables in China // Biological Control. 2014. Vol. 68. P. 92-102. D0l: 10.1016/j.biocontrol.2013.06.012.

24. Van Lenteren J.C., Alomar 0., Ravensberg W.J., Urbaneja A. Biological control agents for control of pests in greenhouses // Integrated Pest and Disease Management in Greenhouse Crops. Plant Pathology in the 21st Century. Vol. 9 / M. Gullino, R. Albajes, P. Nicot (eds.). Springer, 2020. P. 409-439. D0l: 10.1007/978-3-03022304-5_14.

25. Gontijo L.M., Beers E.H., Snyder W.E. Complementary suppression of aphids by predators and parasitoids // Biological Control. 2015. Vol. 90. P. 83-91. D0I: 10.1016/j. biocontrol.2015.06.002.

26. Riddick E.W. Identification of conditions for successful aphid control by ladybirds in greenhouses // Insects. 2017. Vol. 8 (2). P. 1-17. D0I: 10.3390/insects8020038.

(c) Минияров Фарит Талгатович ( fminiyarov@mail.ru ),

Павлов Сергей Иванович ( pavlov@sgspu.ru ), Яицкий Андрей Степанович ( yaitsky@sgspu.ru ).

Журнал «Современная наука: актуальные проблемы теории и практики»

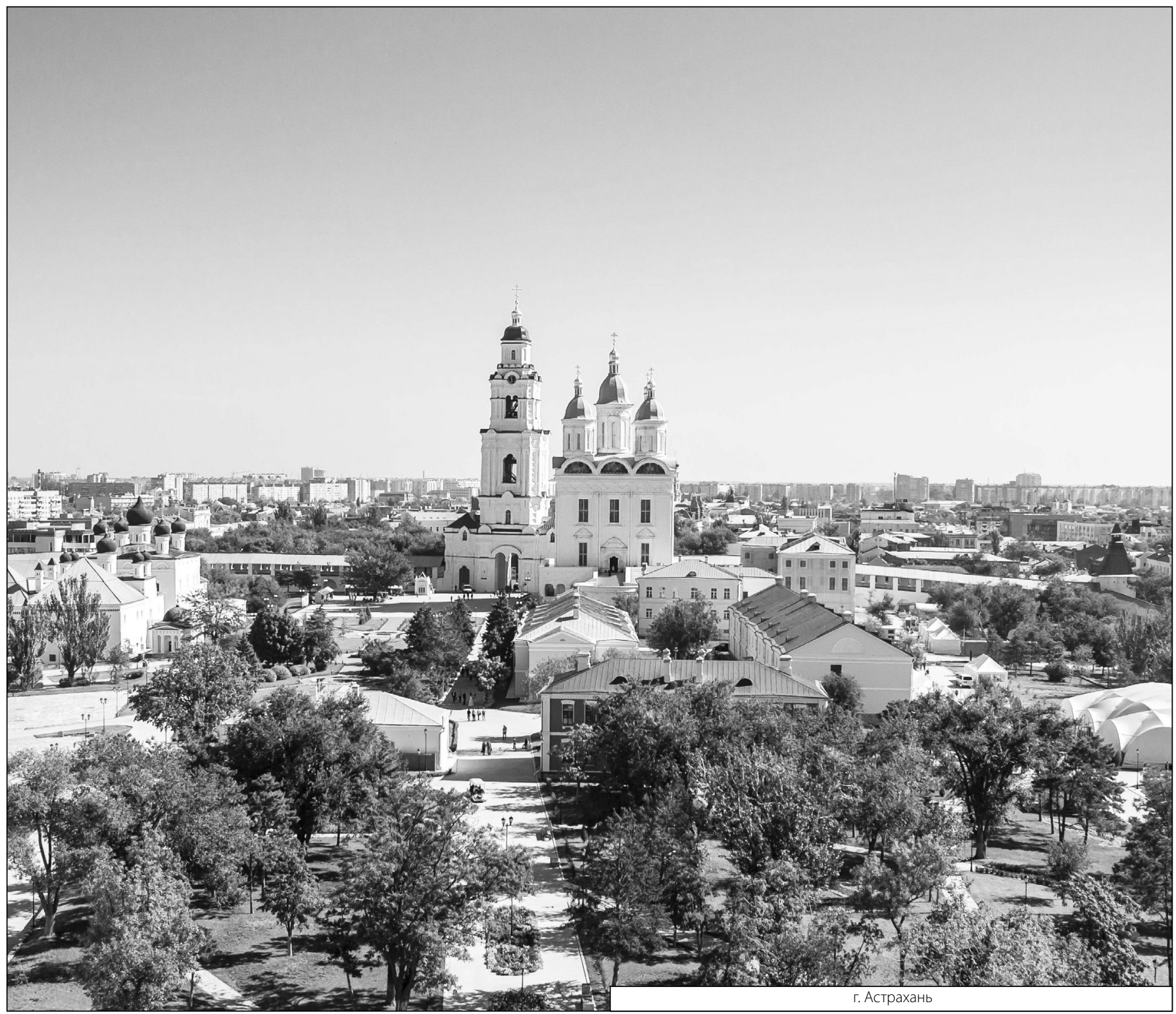

